\title{
A reappraisal of the role of circulating (progenitor) cells in the pathobiology of diabetic complications
}

\author{
G. P. Fadini
}

Received: 14 August 2013 / Accepted: 1 October 2013 /Published online: 31 October 2013

(C) Springer-Verlag Berlin Heidelberg 2013

\begin{abstract}
Traditionally, the development of diabetic complications has been attributed to the biochemical pathways driving hyperglycaemic cell damage, while reparatory mechanisms have been long overlooked. A more comprehensive view of the balance between damage and repair suggests that an impaired regenerative capacity of bone marrow (BM)-derived cells strongly contributes to defective re-endothelisation and neoangiogenesis in diabetes. Although recent technological advances have redefined the biology and function of endothelial progenitor cells (EPCs), interest in BM-derived vasculotropic cells in the setting of diabetes and its complications remains high. Several circulating cell types of haematopoietic and non-haematopoietic origin are affected by diabetes and are potentially involved in the pathobiology of chronic complications. In addition to classical EPCs, these include circulating (pro-)angiogenic cells, polarised monocytes/macrophages (M1 and M2), myeloid calcifying cells and smooth muscle progenitor cells, having disparate roles in vascular biology. In parallel with the study of elusive progenitor cell phenotypes, it has been recognised that diabetes induces a profound remodelling of the BM stem cell niche. The alteration of circulating (progenitor) cells in the $\mathrm{BM}$ is now believed to be the link among distant end-organ complications. The field is rapidly evolving and interest is shifting from specific cell populations to the complex network of interactions that orchestrate trafficking of circulating vasculotropic cells.
\end{abstract}

G. P. Fadini $(\bowtie)$

Department of Medicine, University Hospital of Padova, University of Padova, Via Giustiniani, 2, 35100 Padova, Italy

e-mail: gianpaolo.fadini@unipd.it

G. P. Fadini

Laboratory of Experimental Diabetology,

Venetian Institute of Molecular Medicine, Padova, Italy
Keywords Atherosclerosis · Bone marrow · Endothelium · Regeneration $\cdot$ Review $\cdot$ Stem cells

$\begin{array}{ll}\text { Abbreviations } \\ \text { BM } & \text { Bone marrow } \\ \text { CAC } & \text { Circulating angiogenic cell } \\ \text { CVD } & \text { Cardiovascular disease } \\ \text { ECFC } & \text { Endothelial colony-forming cell } \\ \text { EPC } & \text { Endothelial progenitor cell } \\ \text { G-CSF } & \text { Granulocyte colony-stimulating factor } \\ \text { KDR } & \text { Kinase insert domain receptor } \\ \text { MCC } & \text { Myeloid calcifying cell } \\ \text { OC } & \text { Osteocalcin } \\ \text { PAC } & \text { Pro-angiogenic cell } \\ \text { PBMC } & \text { Peripheral blood mononuclear cell } \\ \text { PKC } & \text { Protein kinase C } \\ \text { vWf } & \text { von Willebrand factor }\end{array}$

Vascular damage and repair in diabetes

For decades, studies on the pathogenesis of vascular disease in diabetes have focused on pathways that translate hyperglycaemia into endothelial cell damage [1]. Those still considered to be major culprits are well summarised by Brownlee's unifying hypothesis, whereby generation of AGE, overactivity of protein kinase $\mathrm{C}$, and the polyol and hexosamine ways are triggered by respiratory chain overflow and oxidative stress [2]. In contrast, vascular repair processes have been long overlooked. In fact, vascular cell turnover is essential to cope with an ineluctable rate of cell senescence and death even in the absence of diabetes or vascular disease. It can therefore be predicted that defects in the mechanisms of repair can worsen, and hence vascular disease can be accelerated, in patients subjected to vascular noxae. Several 
lines of evidence indicate that diabetes should indeed be considered a disease of impaired damage control [3], with defects in the regenerative pathways that normally follow tissue injury. In the vascular system, experimental diabetes has consistently been shown to impair recovery after endothelial denudation [4] and peripheral ischaemia [5-7]. Standardisation of these disease models suggests that impaired responses associated with diabetes are attributable to defective repair rather than excess damage. Traditionally, neoangiogenesis after ischaemia and reendothelisation after endothelial injury were considered to be accomplished through the activation, proliferation and migration of resident endothelial cells. However, following the discovery of endothelial progenitor cells (EPCs), defective re-endothelisation and neoangiogenesis in diabetes have been attributed to circulating EPCs with an impaired regenerative capacity [4, 8], thereby placing circulating cells at the centre of a new pathophysiological model of diabetic vascular disease $[9,10]$. Interest around these cells has been further amplified by the possibility of developing cell-based therapies for vascular complications [11, 12]. On the negative side, as discussed below, alterations induced by the diabetic milieu might even redirect circulating (progenitor) cells to harmful pathways that promote, rather than protect against, the progression of chronic complications, such as proliferative retinopathy, nephropathy and vascular calcification.

\section{Circulating progenitor cells in context}

EPCs were originally described in the late 1990s as bone marrow (BM)-derived circulating immature cells involved in the process of vasculogenesis of the adult organism [13]. The first pioneering papers inspired a huge amount of literature over the subsequent 15 years, providing a wide understanding of the identity, function and regulation of EPCs.

The prevailing view, supported by a wealth of experimental data, was that EPCs are generated from the haemangioblast ancestor in the BM, from where they can be mobilised upon stimulation by growth factors and chemokines triggered by ischaemia or vascular injury. Once in the bloodstream, EPCs follow chemokine gradients to home in on the target tissues, where they promote endothelial repair by adhering to the subendothelial matrix and forming a patch at sites of endothelial denudation. They also promote angiogenesis by physically integrating into the nascent vascular structures and stimulating vascular growth. Following the identification of these two prominent functions, EPCs began to be considered as an integrated component of the cardiovascular system involved in the maintenance of endothelial integrity and vascular health in general. As a consequence, a reduction in the number of circulating EPCs and dysfunctional circulating EPCs are considered to be significant contributors to the onset and progression of vascular disease in many clinical conditions, including type 1 and type 2 diabetes [10]. Notably, several therapies, ranging from lifestyle changes to common and experimental pharmacological approaches, have been reported to be effective in restoring the number or function of EPCs, including glucose-lowering medications [14].

Over the last 5 years, this amazingly consistent scenario has been challenged by technological advances that have given us a better definition of several aspects of EPC biology and function (Table 1) [15]. First, confocal imaging has been used to analyse assays of peripheral endothelium repair and angiogenesis and revealed that the contribution made by BM-derived cells is smaller than was previously believed, or even negligible [16-18]. Indeed, most BM-derived progenitor cells that home in to the injured vasculature or ischaemic tissues are localised in the perivascular space and rarely integrate into the endothelial layer. Furthermore, the most commonly used methods for isolating EPCs in culture have been found to generate a mixed population of myeloid cells (monocytes and macrophages) assuming an endothelial-like phenotype by virtue of expression of some, not unequivocal, endothelial markers, such as vascular endothelial growth factor receptor-2 (VEGF-R2), CD31 and von Willebrand factor (vWf). Primary short-term cultures of peripheral blood mononuclear cells (PBMCs) under culture conditions used for endothelial cells are also contaminated by $\mathrm{T}$ lymphocytes and do not normally select or expand stem/progenitor cells [19]. These cells have since been assigned alternative names, such as myeloid EPCs, early EPCs, colony-forming units (CFU)Hill, circulating angiogenic cells (CACs) and pro-angiogenic cells (PACs). While significant heterogeneity still exists among the various protocols, the general consensus is that the term 'progenitor cells' should not be used to identify such cells, which are nonetheless able to support angiogenesis and vascular repair by indirect paracrine activities [20, 21]. Although endothelial reprogramming of mononuclear cells occurs to a certain extent in vitro, it is normally incomplete as a result of epigenetic brakes, such as persistent promoter methylation of the gene encoding endothelial nitric oxide synthase (eNOS) [22]. This scenario is further complicated by the finding that the cultures are contaminated by plateletderived microparticles, which spuriously confer endotheliallike properties (such as CD31/vWf expression and lectinbinding) to the myeloid cells [23]. In summary, cells in socalled EPC cultures resemble endothelial cells but most of them are not progenitors of mature endothelium, either ontologically or genetically [24]. Thus, while the acronym 'EPC' is still used mainly for comparison with existing literature, the term 'progenitor cell' should be avoided or used 
Table 1 Old and new paradigms in EPC biology and function

\begin{tabular}{|c|c|c|}
\hline Issue & Old view & Modern view \\
\hline $\begin{array}{l}\text { Identity of cultured EPCs } \\
\text { (early, myeloid, } \\
\text { CACs, PACs) }\end{array}$ & $\begin{array}{l}\text { Vascular stem/progenitor } \\
\text { cells committed to the } \\
\text { endothelial lineage }\end{array}$ & $\begin{array}{l}\text { A heterogeneous } \\
\text { cell population composed } \\
\text { of endothelial-like myeloid } \\
\text { cells, lymphocytes and rare } \\
\text { stem/progenitor cells }\end{array}$ \\
\hline $\begin{array}{l}\text { Identity of circulating EPCs defined } \\
\text { by surface antigens using FACS }\end{array}$ & $\mathrm{CD} 4^{+} \mathrm{KDR}^{+}\left(\mathrm{CD} 133^{+}\right)$ & $\mathrm{CD} 45^{\mathrm{dim} /-} \mathrm{CD} 34^{+}\left(\mathrm{KDR}^{+}\right)$ \\
\hline $\begin{array}{l}\text { Activity of BM-derived EPCs } \\
\text { in vivo (cell tracking } \\
\text { experiments) }\end{array}$ & $\begin{array}{l}\text { Integration into peripheral } \\
\text { endothelium and formation } \\
\text { of new blood vessel }\end{array}$ & $\begin{array}{l}\text { Perivascular integration } \\
\text { and paracrine supporting } \\
\text { activity of endothelial } \\
\text { healing and angiogenesis }\end{array}$ \\
\hline $\begin{array}{l}\text { Identity of cultured ECFCs } \\
\text { (or late EPCs, OECs) }\end{array}$ & $\begin{array}{l}\text { EPCs at a later stage } \\
\text { of maturation }\end{array}$ & $\begin{array}{l}\text { A separated clonogenic } \\
\text { cell type with complete } \\
\text { endothelial differentiation }\end{array}$ \\
\hline $\begin{array}{l}\text { Identity of circulating ECFCs } \\
\text { defined by surface } \\
\text { antigens using FACS }\end{array}$ & Unknown & $\mathrm{CD} 45^{-} \mathrm{CD} 34^{+}\left(\mathrm{CD} 31^{+} \mathrm{CD} 146^{+}\right)$ \\
\hline $\begin{array}{l}\text { Activity of ECFCs } \\
\text { (or late EPCs, OECs) }\end{array}$ & $\begin{array}{l}\text { Integration into peripheral } \\
\text { endothelium and } \\
\text { formation of new } \\
\text { blood vessel }\end{array}$ & $\begin{array}{l}\text { Integration into peripheral } \\
\text { endothelium and formation } \\
\text { of new blood vessel }\end{array}$ \\
\hline
\end{tabular}

OECs, outgrowing endothelial cells
While the original phenotype $\mathrm{CD}_{3} 4^{+}$kinase insert domain receptor $(\mathrm{KDR})^{+}$might still be valid for haematopoietic EPCs, this definition overlaps in part with hematopoietic stem/progenitor cells and circulating endothelial cells. In view of the recently demonstrated endothelial-haematopoietic transition [34], this overlap should not diminish the interest in these BM-derived cells. Rather, CD34 ${ }^{+}$cells in the CD45 fraction eventually co-expressing other endothelial markers (e.g. CD31 and CD146), are enriched in proliferating endothelial cells, generate ECFCs in vitro [28] and are regarded as non-haematopoietic EPCs.

Based on this critical re-assessment, BM-derived pro-angiogenic cells now appear to be pathophysiologically linked to the plasticity of monocyte-macrophage lineage cells, and are believed to aid endothelial healing and angiogenesis via indirect cell-supporting activities.

While EPCs are the most extensively characterised of the putative circulating progenitor cells, data support the existence of BM-derived cells contributing to the smooth muscle cell population in the peripheral vasculature [35], although this finding is controversial [36].

Notwithstanding complex and as yet unresolved criticism, it is still believed that alterations in the biology of circulating (progenitor) cells and myeloid cell plasticity play a role in the pathogenesis of diabetic vascular disease. It is also important to emphasise that, beyond ongoing controversies regarding the exact definition and function of such cells, clinical trials have shown some degree of efficacy using BM-derived cells for the treatment of cardiovascular disease (CVD). Metaanalyses of autologous cell therapy trials for acute myocardial infarction [37, 38] and chronic ischaemic heart disease [39, 
40] have shown significant short-term improvements in surrogate endpoints (e.g. ejection fraction), with possible improvements in hard endpoints with longer follow-up. Similarly, in the setting of peripheral arterial disease and critical limb ischaemia, autologous BM cell therapy produced improvements in limb perfusion surrogates, pain, functional status and, possibly, wound healing [11]. While it was once believed that injected/infused cells could transdifferentiate into vascular wall cells and/or cardiomyocytes, this is now considered a very rare phenomenon and other indirect mechanisms of action must account for such clinical findings. Studies on cell identity, function and kinetics have the potential to elucidate such mechanisms and help to optimise cell-based or cell-oriented therapies for CVD and diabetic macroangiopathy.

\section{Circulating (progenitor) cell phenotypes and diabetic complications}

EPCs Diabetes is one of the clinical conditions in which alterations in EPCs have been studied in greatest detail; several studies have consistently reported that EPCs are reduced in number and are dysfunctional in patients with type 1 or type 2 diabetes [41]. This is thought to impair vascular health in diabetic patients, thus contributing to the onset or progression of micro- or macroangiopathy [10]. The reduction of the circulating CD $34^{+}$progenitor cell pool (the ancestor of all EPC phenotypes) occurs at an early stage in the natural history of type 2 diabetes and can be demonstrated in individuals with impaired glucose tolerance [42]. The depletion of progenitor cells persists over time and is worse in patients with advanced complications [43, 44]. Indeed, the levels of $\mathrm{CD} 4^{+} \mathrm{KDR}^{+}$EPCs are strongly negatively correlated to the degree of peripheral vascular complications in type 2 diabetes [45]. Consistent with the indirect protective effects of EPCs on the cardiovascular system, depletion of the number of circulating EPCs is associated with an excess incidence of cardiovascular events in different populations [46], including patients with diabetes and the metabolic syndrome [47]. Early EPCs (CACs or PACs) are reduced in number and display profound dysfunctions in uncomplicated type 2 diabetes compared with controls [48], which are more profound in the presence of macroangiopathy [45]. The link between hyperglycaemia and altered EPCs is strongly supported by studies in type 1 diabetes. Type 1 diabetes causes early EPC dysfunction that is quite similar to that observed in type 2 diabetes [49]. Circulating $\mathrm{CD} 34^{+} \mathrm{KDR}^{+} \mathrm{EPCs}$ are reduced in number in young type 1 diabetic patients compared with controls, particularly in those with suboptimal glucose control [50], a longer diabetes duration, microangiopathy [51, 52] and initial signs/surrogates of macroangiopathy $[53,54]$.
The overall complication burden has been shown to have a negative impact on the levels of different progenitor cell populations [55] (Table 2, Fig. 1). Taking into account several clinical studies, it emerges that alterations in EPCs follow the natural history of atherosclerosis, from its development to later stage complications of the plaque $[15,56]$. While macroangiopathy and incident CVD have consistently been associated with EPC reduction/dysfunction, there have been fewer studies on the effect of microangiopathy. Studies in patients with chronic renal failure receiving dialysis have shown markedly impaired EPCs, both in culture and in the circulation [57], but specific studies on diabetic nephropathy are rare. While Reinhard et al found no alteration in early EPC cultures obtained from type 1 diabetic patients with, compared with those without, nephropathy [58], Dessapt et al found lower levels of $\mathrm{CD} 34^{+}$and $\mathrm{CD} 34^{+} \mathrm{CD} 133^{+}$cells in type 1 diabetic patients with, compared with those without, microalbuminuria [51], and Makino et al reported that $\mathrm{CD} 34^{+}$cell count is a predictor of albuminuria progression in type 2 diabetes [59]. Based on these inconsistent data, the relationship between the presence/evolution of diabetic nephropathy and alterations in EPCs needs further clarification.

As EPCs are endowed with (indirect) pro-angiogenic activity, they may have a Janus-faced role in the different stages of retinopathy. Several reports have shown increased circulating $\left(\mathrm{CD} 34^{+} \mathrm{KDR}^{+}\right)$and cultured early EPCs in patients with advanced or proliferative retinopathy [52, 60-63]. Such an excess of EPCs may contribute to pathological retinal angiogenesis, as shown in experimental models $[64,65]$, but longitudinal and clinical studies linking EPC levels to outcomes of advanced retinopathy are needed to support this hypothesis in human diabetes.

Finally, it must be noted that virtually no clinical study has so far evaluated the relationship between EPCs and diabetic neuropathy. Therefore, this should be an area of intense investigation, especially in view of experimental studies showing that an EPC-targeted approach is a promising therapy for diabetic neuropathy [66, 67], a disabling condition with limited treatment options.

Monocyte-macrophage polarisation In contrast to what was originally believed, several aspects of EPC biology can now be traced back to the plasticity of the monocyte-macrophage lineage [68-70]. Monocytes-macrophages can roughly be distinguished into classical proinflammatory M1 and alternative (or non-classical) M2, with different phenotypes and functions [71]. Importantly, similar to myeloid EPCs, M2 monocytes-macrophages appear to be enriched in cells that indirectly support angiogenesis, [72-74]. The existence of angiogenic monocytes-macrophages, identified by expression of the angiopoietin receptor TIE2 (so-called TIE2-expressing macrophages), is well known from studies 
Table 2 An overview of EPCs in diabetic complications

\begin{tabular}{|c|c|c|}
\hline Complication & Cell type & Observation \\
\hline \multirow[t]{4}{*}{ Macroangiopathy } & $\mathrm{CD}_{3} 4^{+}$ & Reduced in PVD [43] \\
\hline & $\mathrm{CD} 4^{+} \mathrm{KDR}^{+}$ & $\begin{array}{l}\text { Progressively reduced in parallel to severity of } \\
\text { carotid atherosclerosis and arteriosclerosis } \\
\text { obliterans }[43,45]\end{array}$ \\
\hline & \multirow[t]{2}{*}{ Cultured CACs/PACs } & $\begin{array}{l}\text { Reduced adhesion and proliferation in PVD } \\
\text { patients [45] }\end{array}$ \\
\hline & & $\begin{array}{l}\text { Reduced in patients with vs those without } \\
\text { MVD [100] }\end{array}$ \\
\hline Cardiomyopathy & $\mathrm{CD}_{3} 4^{+}$ & $\begin{array}{l}\text { Reduced in patients with left ventricular } \\
\text { dysfunction without CAD [121] }\end{array}$ \\
\hline \multirow[t]{3}{*}{ Nephropathy } & $\mathrm{CD}_{3} 4^{+}$ & $\begin{array}{l}\text { Lower levels are associated with microalbuminuria } \\
\text { [51] and predict progression of albuminuria [59] }\end{array}$ \\
\hline & $\mathrm{CD}_{3} 4^{+} \mathrm{CD} 133^{+}$ & $\begin{array}{l}\text { Lower levels are associated with microalbuminuria } \\
\text { [51] }\end{array}$ \\
\hline & Cultured CACs/PACs & $\begin{array}{l}\text { Impaired proliferation and tube formation in } \\
\text { microalbuminuric patients [51]; no difference } \\
\text { between microalbuminuric and normoalbuminuric } \\
\text { patients [58] }\end{array}$ \\
\hline \multirow[t]{4}{*}{$\begin{array}{l}\text { Retinopathy (in the absence } \\
\text { of macroangiopathy) }\end{array}$} & $\mathrm{CD} 4^{+} \mathrm{CD} 133^{+} \mathrm{KDR}^{+}$ & $\begin{array}{l}\text { Reduced in non-proliferative retinopathy and } \\
\text { increased in proliferative retinopathy [52] }\end{array}$ \\
\hline & $\mathrm{CD} 34^{+} \mathrm{CD} 45^{-}$ & Increased in proliferative retinopathy [61] \\
\hline & CACs/early EPCs & $\begin{array}{l}\text { Increased clonogenic potential in proliferative } \\
\text { retinopathy }[60,62]\end{array}$ \\
\hline & ECFCs & $\begin{array}{l}\text { Impaired migratory activity and tubulisation in } \\
\text { proliferative retinopathy [61] }\end{array}$ \\
\hline \multirow[t]{2}{*}{ Diabetic foot } & $\mathrm{CD} 34^{+}$ & \multirow{2}{*}{$\begin{array}{l}\text { Reduced in patients with PVD and foot ulcers } \\
\text { compared with PVD patients without ulcers [43] }\end{array}$} \\
\hline & $\mathrm{CD}_{3} 4^{+} \mathrm{KDR}^{+}$ & \\
\hline
\end{tabular}

$\mathrm{CAD}$, coronary artery disease; MVD, multivessel disease; PVD, peripheral vascular disease than an excess of proinflammatory M1 [81]. Taking into account that the M2 population contains PACs, this can easily be viewed as part of the impaired damage control in diabetes. Importantly, derangements of M2 regulation were associated with BM dysfunction and microangiopathy (especially nephropathy) [81], representing a possible link between distant organ complications. The study of M1/M2 polarisation can also provide novel insights into cardiovascular risk associated with pre-diabetes, as we have shown that individuals with impaired fasting glucose/impaired glucose tolerance have an excess of proinflammatory M1 cells with a distinctive cholesterol handling capacity [82].

Circulating calcifying cells Diabetes is typically characterised by accelerated vascular calcification, but the mechanisms and molecular pathways involved are largely unknown. We have found that expression of the bone-related markers osteocalcin (OC) and bone alkaline phosphatase (BAP) on $\mathrm{CD} 34^{+}$cells is markedly increased in type 2 diabetic patients with coronary artery disease, paralleled by a reduction of endothelial marker expression [83]. In vitro, PACs from type 2 diabetic patients occasionally formed mineralised nodules, and the osteogenic programme could be recapitulated by treating cells with 
Fig. 1 Origin and function of circulating (progenitor) cell phenotypes in diabetic complications. While the BM haemangioblast is considered to be the origin of classical true EPCs, ECFCs are believed to derive from the vessel wall. In addition, early EPCs (more properly renamed as CACs or PACs), smooth muscle progenitor cells (SMPCs) and M1/M2 phenotype originate from the monocyte-macrophage lineage. Red symbols indicate the direction of quantitative changes in the various cell types. ED, endothelial dysfunction; IMT, intima-media thickening

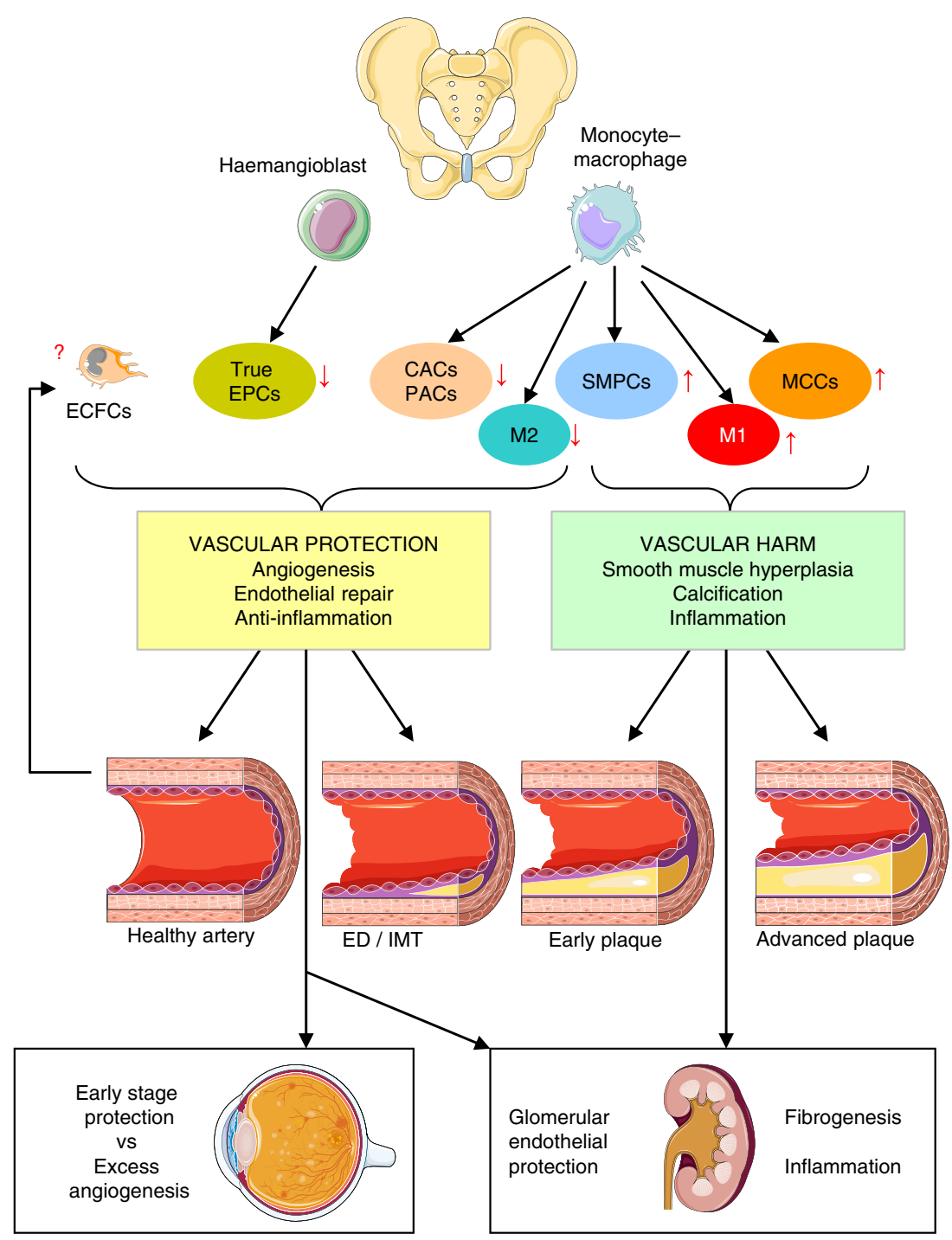

lipopolysaccharide [83], suggesting that this derangement occurs in the setting of inflammation. Theoretically, this endothelial-to-procalcific shift of circulating cell differentiation has the potential to deliver a calcifying stimulus to the vasculature via cells that are naturally instructed to enter the vessel wall thanks to their armamentarium of adhesion molecules and chemokine receptors [84, 85]. This hypothesis is confirmed by the observation that osteogenic EPCs are selectively retained in the coronary circulation of patients with coronary endothelial dysfunction [86]. Excess OC-expressing procalcific EPCs are associated with diabetes [87], calcific aortic stenosis [88], coronary atherosclerosis [89], and history of myocardial infarction [90]. Thus, pro-calcific polarisation represents the other side of the coin in EPC biology and is thought to turn cells that are normally vasculoprotective into a potential pathogenetic factor. However, it would be surprising if extensive vascular calcifications are attributable to a very rare $(<0.01 \%)$ population of cells, such as OC-expressing
EPCs. Therefore, efforts have been dedicated to identifying other populations of circulating calcifying cells in the framework of the so-called 'bone-vascular axis' [91]. We found that $\mathrm{OC}^{+} \mathrm{BAP}^{+}$monocytes, accounting for up to $3-4 \%$ of blood cells, show activation of the osteogenic master gene $R U N X 2$, are able to calcify in vitro and in vivo and are found in increased numbers in the circulation, BM and atherosclerotic plaques of type 2 diabetic patients [92]. These myeloid calcifying cells (MCCs) can also be isolated from the murine spleen and promote calcification of early and advanced atherosclerotic lesions via paracrine activity and overexpression of the macrophage activation marker allograft inflammatory factor (AIF)-1 [93]. While extensively calcified lesions may be more stable than lipid-rich lesions, spotty neointimal calcifications are believed to increase the vulnerability of lesions and their probability of rupture [94, 95]. Therefore, MCCs could contribute to the excess risk of atherothrombotic events in diabetic patients. Interestingly, 
human MCCs also possess anti-angiogenic properties in vitro and in vivo, through both cell-intrinsic and paracrine activities, the latter mediated by high levels of expression of the anti-angiogenic molecule thrombospondin-1 [96]. How the two functions of these cells integrate in a physiological model is unclear, but it can be speculated that induction of calcification with simultaneous inhibition of angiogenesis is a late attempt to confine a chronic inflammatory stimulus, be it a foreign body or cholesterol crystals. The discovery of this osteogenic and anti-angiogenic monocyte subpopulation has clear implications for the development of diabetic macroangiopathy, which is in fact characterised by excess calcification and impaired collateralisation $[97,98]$.

Smooth muscle progenitor cells As outlined above for MCCs, it is emerging that diabetes not only reduces the number of vasculoprotective cells, but also promotes the generation of BM-derived cells that are detrimental to cardiovascular homeostasis. It also promotes the differentiation of BM progenitor cells toward the smooth muscle phenotype [99]. Outgrowth of smooth muscle progenitor cells from PBMCs in diabetic patients does not appear to be balanced by the outgrowth of CACs [100], implying a differentiation drift towards smooth muscle at the expense of the endothelial phenotype. In the same study, however, the level of putative $\mathrm{CD} 14^{+} \mathrm{CD} 105^{+}$smooth muscle progenitors was increased in non-diabetic patients with peripheral arterial disease, but was not associated with diabetes [100]. Although putative smooth muscle progenitor cells have been isolated from peripheral blood and BM [35], whether BM-derived cells contribute to smooth muscle hyperplasia in atherosclerotic plaques is still debated. Fledderus et al demonstrated that the accelerated atherosclerosis in diabetic Apoe-null mice is characterised by an excess of BM-derived cells with a smooth muscle-like phenotype in the plaques, compared with non-diabetic Apoenull control mice [101]. However, in a murine model of allograft vasculopathy, which is primarily characterized by smooth muscle proliferation, Hagensen et al found no contribution of circulating cells [36], questioning the paradigm of BM-derived smooth muscle progenitors. Similarly, in young or old Apoe-null mice the contribution of BM-derived cells appeared to be very small or negligible [102-104]. Such controversy is probably related to methodological issues inherent to the experimental model used, because apolipoprotein E (ApoE) itself has been shown to regulate BM-stem progenitor cell trafficking (critically discussed in [99]). In any case, whether the presence of BM-derived smooth muscle cells in the diseased vasculature is a pathogenic phenomenon or a reparative attempt remains to be elucidated. This scenario is further complicated by the observation that BM-derived EPCs can assume a smooth muscle-like phenotype in the vasculature in response to local stimuli, such as TGF- $\beta$ [105-107]. The potential role of smooth muscle progenitors is not limited to macroangiopathy, as differentiation of cells with a smooth muscle-like phenotype may have negative implications for the development and progression of microangiopathy, especially nephropathy. Nguyen et al reported that a culture protocol similar to those optimised to yield early EPCs generates an excess of myofibroblasts in type 1 diabetic patients compared with controls [108]. These cells can be expected to deliver pro-fibrogenic signals to the diabetic kidney and facilitate glomerulosclerosis [109].

\section{The BM in diabetes}

The molecular mechanisms of progenitor cell alterations in diabetes and its complications are complex and highly diversified, especially in relation to the wide heterogeneity of culture protocols. A review of such molecular pathways can be found elsewhere [110] and goes beyond the scope of the present manuscript. However, it is worth mentioning that investigations into the causes of the reduced number of $\mathrm{CD} 34^{+}$cells and EPCs in diabetes recently led to the discovery that diabetes strongly affects BM structure and function [111]. Diabetic rats show an inappropriately low mobilisation of BM stem cells in response to tissue ischaemia and granulocyte colony-stimulating factor (G-CSF) [112]. A reduced response to G-CSF-induced mobilisation in type 1 and type 2 diabetes models has been confirmed in mice [113]. Diabetic patients are also unresponsive to the effects of G-CSF, which fails to mobilise CD $34^{+}$cells and EPCs [114, 115]. This is likely to be due to the profound remodelling induced by diabetes in the BM microenvironment. In fact, both in mice [116] and in humans [117] the diabetic BM is characterised by microangiopathy and alterations of the stem cell niche. These very recent data not only provide a mechanistic explanation for the impaired vascular repair by BM-derived cells, but also identify the BM as a hitherto overlooked site of diabetic microangiopathy, with important implications for the clustering among distant end-organ complications. Interestingly, the diabetic BM shows microangiopathic features that are quite similar to those typical of diabetic retinopathy, such as increased permeability [118]. Other features of the diabetic $\mathrm{BM}$ are summarised in the text box below. Therapeutic strategies aimed at restoring the BM architecture and boost its endogenous regenerative cells represent attractive targets to slow down the progression of diabetic complications. 


\section{Features of the diabetic BM}

- In mice, type 1 diabetes induces microvascular rarefaction, increased permeability, alterations of the niche, and depletion of stem cells [116, 118].

- In mice, type 1 diabetes alters BM niche function, gene expression and cytokine production [113, 122-124].

- In rats, induction of mobilisation of stem cells from the BM to peripheral blood by ischaemia $[112,125]$ and G-CSF $[113,124]$ is impaired in type 1 diabetes.

- In rats, type 2 diabetes is associated with autonomic neuropathy in the BM, which affects release of stem cells [126].

- In humans, type 2 diabetes causes a reduction of haematopoietic tissue, fat deposition, and microvascular rarefaction, especially when associated with vascular disease [117].

- In humans, diabetes impairs the mobilisation of stem/ progenitor cells after G-CSF [112, 114] and myocardial infarction [127].

\section{Concluding remarks and future directions}

Although the field of vascular progenitor cell investigation has significantly evolved during the last 10 years, our knowledge of the complexity of the biology and function of these cells is still incomplete. Since their identification as intelligent bricks of the vessel wall, BM-derived $\mathrm{E}(\mathrm{P}) \mathrm{Cs}$ have been redefined as clever coadjuvants of vascular homeostasis, antagonised by harmful cellular by-products, such as MCCs and smooth muscle progenitors.

It is at present unclear whether alterations of circulating (progenitor) cells are merely associated with diabetes or are causatively related to chronic complications and, if so, which are involved. Although we know what the functions of EPCs are, there is a lack of compelling experimental evidence that EPC reductions/alterations cause chronic diabetic complications. Importantly, most pre-clinical studies using animal models have tried to reverse, treat or prevent features of diabetic complications by increasing, modulating or engineering autologous EPCs or by providing exogenous EPCs. Experiments trying to mimic human diabetes-associated EPC defects to evaluate their impact on vascular biology are often biased and difficult to interpret owing to the widespread effects of the underlying condition (e.g. streptozotocin treatment and hyperglycaemia). A targeted and specific approach for the evaluation of the micro-/macrovascular effects of selectively depleting EPCs from the bloodstream is needed to answer such a question, but this has yet to be devised.

Meanwhile, studies on diabetes and its complications have moved from the simplistic analysis of circulating (progenitor) cell number and function to evaluating the regulation of stem/ progenitor cell kinetics and exploring the BM microenvironment. While the appeal of therapies using autologous BM-derived cells is diminishing, a new scenario is emerging whereby complex interactions among the $\mathrm{BM}$ hematopoietic niche, circulating blood cells and the vasculature affect the pathobiology of diabetic complications [111]. Thus, interest is shifting from the quantification and characterisation of definite cell populations to the study of the networks that govern circulating cells with vasculotropic properties. Within this framework, the next frontier is to pursue a therapy that endogenously re-educates BM-derived vasculoprotective cells and modulates the processes that orchestrate their niche and trafficking. Unexpectedly, this can be accomplished to some extent by studying the offtarget effects of known therapies. For example, dipeptidyl peptidase 4 (DPP-4) inhibitors [119] and peroxisome proliferation activator receptor $\gamma$ (PPAR- $\gamma$ ) agonists [120] have consistently shown the capacity to stimulate EPCs acting on molecular pathways that are altered in diabetic cells. Ideally, this could help to achieve a higher degree of therapeutic individualisation targeted to cellular alterations that are both biomarkers and pathogenic factors.

Finally, there are several unresolved issues regarding circulating (progenitor) cells and diabetic complications; these are summarised in the text box below. Importantly, although several progenitor cell levels have been shown to be inversely predictive of advance outcomes, whether EPC stimulation per se is able to modify the natural history of complications or cardiovascular risk in diabetic patients is unknown. From a clinical perspective, this is one of the most relevant challenges that we need to take on.

\section{Unresolved issues and areas of future investigation}

- Specific longitudinal studies on EPC/CD $34^{+}$cell levels and cardiovascular events in the diabetic population are missing.

- The association between circulating EPCs, cultured CACs and ECFCs in relation to microalbuminuria in type 1 and type 2 diabetes is controversial.

- Longitudinal studies on EPC levels and outcomes of retinopathy are missing.

- The association between circulating and cultured (progenitor) cells and diabetic neuropathy is unexplored.

- Whether therapeutically increasing EPCs/CACs improves long-term diabetes-related outcomes is completely unknown.

- The relationships between bone marrow structure/ function and diabetic micro- and macroangiopathy is an emerging area of investigation. 
Duality of interest The author declares that there is no duality of interest associated with this manuscript.

Contribution statement The author was the sole contributor to this review.

\section{References}

1. Avogaro A, de Kreutzenberg SV, Fadini G (2008) Endothelial dysfunction: causes and consequences in patients with diabetes mellitus. Diabetes Res Clin Pract 82(Suppl 2):S94-S101

2. Brownlee M (2005) The pathobiology of diabetic complications: a unifying mechanism. Diabetes 54:1615-1625

3. Schaper NC, Havekes B (2012) Diabetes: impaired damage control. Diabetologia 55:18-20

4. Ii M, Takenaka H, Asai J et al (2006) Endothelial progenitor thrombospondin-1 mediates diabetes-induced delay in reendothelialization following arterial injury. Circ Res 98:697-704

5. Rivard A, Silver M, Chen D et al (1999) Rescue of diabetes-related impairment of angiogenesis by intramuscular gene therapy with adeno-VEGF. Am J Pathol 154:355-363

6. Ebrahimian TG, Heymes C, You D et al (2006) NADPH oxidasederived overproduction of reactive oxygen species impairs postischemic neovascularization in mice with type 1 diabetes. Am J Pathol 169:719-728

7. Hazarika S, Dokun AO, Li Y et al (2007) Impaired angiogenesis after hindlimb ischemia in type 2 diabetes mellitus: differential regulation of vascular endothelial growth factor receptor 1 and soluble vascular endothelial growth factor receptor 1. Circ Res 101:948-956

8. Sorrentino SA, Bahlmann FH, Besler C et al (2007) Oxidant stress impairs in vivo reendothelialization capacity of endothelial progenitor cells from patients with type 2 diabetes mellitus: restoration by the peroxisome proliferator-activated receptorgamma agonist rosiglitazone. Circulation 116:163-173

9. Fadini GP, Agostini C, Avogaro A (2005) Endothelial progenitor cells and vascular biology in diabetes mellitus: current knowledge and future perspectives. Curr Diabetes Rev 1:41-58

10. Fadini GP, Sartore S, Agostini C, Avogaro A (2007) Significance of endothelial progenitor cells in subjects with diabetes. Diabetes Care 30:1305-1313

11. Fadini GP, Agostini C, Avogaro A (2010) Autologous stem cell therapy for peripheral arterial disease meta-analysis and systematic review of the literature. Atherosclerosis 209:10-17

12. Clifford DM, Fisher SA, Brunskill SJ et al (2012) Stem cell treatment for acute myocardial infarction. Cochrane Database Syst Rev (2) Art. no.:CD006536. doi:10.1002/14651858.CD006536. pub3

13. Asahara T, Murohara T, Sullivan A et al (1997) Isolation of putative progenitor endothelial cells for angiogenesis. Science 275:964-967

14. Fadini GP, Avogaro A (2010) Potential manipulation of endothelial progenitor cells in diabetes and its complications. Diabetes Obes Metab 12:570-583

15. Fadini GP, Losordo D, Dimmeler S (2012) Critical reevaluation of endothelial progenitor cell phenotypes for therapeutic and diagnostic use. Circ Res 110:624-637

16. Hagensen MK, Raarup MK, Mortensen MB et al (2012) Circulating endothelial progenitor cells do not contribute to regeneration of endothelium after murine arterial injury. Cardiovasc Res 93:223-231

17. Hagensen MK, Shim J, Thim T, Falk E, Bentzon JF (2010) Circulating endothelial progenitor cells do not contribute to plaque endothelium in murine atherosclerosis. Circulation 121:898-905
18. Wickersheim A, Kerber M, de Miguel LS, Plate KH, Machein MR (2009) Endothelial progenitor cells do not contribute to tumor endothelium in primary and metastatic tumors. Int $\mathrm{J}$ Cancer 125:1771-1777

19. Desai A, Glaser A, Liu D et al (2009) Microarray-based characterization of a colony assay used to investigate endothelial progenitor cells and relevance to endothelial function in humans. Arterioscler Thromb Vasc Biol 29:121-127

20. Rehman J, Li J, Orschell CM, March KL (2003) Peripheral blood "endothelial progenitor cells" are derived from monocyte/ macrophages and secrete angiogenic growth factors. Circulation 107:1164-1169

21. Urbich C, Aicher A, Heeschen C et al (2005) Soluble factors released by endothelial progenitor cells promote migration of endothelial cells and cardiac resident progenitor cells. J Mol Cell Cardiol 39:733-742

22. Ohtani K, Vlachojannis GJ, Koyanagi M et al (2011) Epigenetic regulation of endothelial lineage committed genes in pro-angiogenic hematopoietic and endothelial progenitor cells. Circ Res 109:1219-1229

23. Prokopi M, Pula G, Mayr U et al (2009) Proteomic analysis reveals presence of platelet microparticles in endothelial progenitor cell cultures. Blood 114:723-732

24. Yoder MC, Mead LE, Prater D et al (2007) Redefining endothelial progenitor cells via clonal analysis and hematopoietic stem/ progenitor cell principals. Blood 109:1801-1809

25. He T, Smith LA, Harrington S et al (2004) Transplantation of circulating endothelial progenitor cells restores endothelial function of denuded rabbit carotid arteries. Stroke 35:2378-2384

26. Giannotti G, Doerries C, Mocharla PS et al (2010) Impaired endothelial repair capacity of early endothelial progenitor cells in prehypertension: relation to endothelial dysfunction. Hypertension 55:1389-1397

27. Yoder MC (2010) Is endothelium the origin of endothelial progenitor cells? Arterioscler Thromb Vasc Biol 30:1094-1103

28. Mund JA, Estes ML, Yoder MC, Ingram DA Jr, Case J (2012) Flow cytometric identification and functional characterization of immature and mature circulating endothelial cells. Arterioscler Thromb Vasc Biol 32:1045-1053

29. Tura O, Skinner EM, Barclay GR et al (2013) Late outgrowth endothelial cells resemble mature endothelial cells and are not derived from bone marrow. Stem Cells 31:338-348

30. Thebaud NB, Bareille R, Remy M et al (2010) Human progenitorderived endothelial cells vs. venous endothelial cells for vascular tissue engineering: an in vitro study. J Tissue Eng Regen Med 4:473-484

31. Fadini GP, Agostini C, Avogaro A (2007) Endothelial progenitor cells in coronary artery disease. J Am Coll Cardiol 49:1585, author reply $1585-1586$

32. Zeisberger SM, Zoller S, Riegel M et al (2010) Optimization of the culturing conditions of human umbilical cord blood-derived endothelial colony-forming cells under xeno-free conditions applying a transcriptomic approach. Genes Cells 15:671-687

33. Masuda H, Iwasaki H, Kawamoto A et al (2012) Development of serum-free quality and quantity control culture of colony-forming endothelial progenitor cell for vasculogenesis. Stem Cells Transl Med $1: 160-171$

34. Kissa K, Herbomel P (2010) Blood stem cells emerge from aortic endothelium by a novel type of cell transition. Nature 464:112-115

35. Albiero M, Menegazzo L, Fadini GP (2010) Circulating smooth muscle progenitors and atherosclerosis. Trends Cardiovasc Med 20:133-140

36. Hagensen MK, Shim J, Falk E, Bentzon JF (2011) Flanking recipient vasculature, not circulating progenitor cells, contributes to endothelium and smooth muscle in murine allograft vasculopathy. Arterioscler Thromb Vasc Biol 31:808-813 
37. Delewi R, Andriessen A, Tijssen JG et al (2013) Impact of intracoronary cell therapy on left ventricular function in the setting of acute myocardial infarction: a meta-analysis of randomised controlled clinical trials. Heart 99:225-232

38. Jeevanantham V, Butler M, Saad A et al (2012) Adult bone marrow cell therapy improves survival and induces long-term improvement in cardiac parameters: a systematic review and meta-analysis. Circulation 126:551-568

39. Fisher SA, Doree C, Brunskill SJ, Mathur A, Martin-Rendon E (2013) Bone marrow stem cell treatment for ischemic heart disease in patients with no option of revascularization: a systematic review and meta-analysis. PLoS One 8:e64669

40. Kandala J, Upadhyay GA, Pokushalov E et al (2013) Meta-analysis of stem cell therapy in chronic ischemic cardiomyopathy. Am J Cardiol 112:217-225

41. Fadini GP (2008) An underlying principle for the study of circulating progenitor cells in diabetes and its complications. Diabetologia 51:1091-1094

42. Fadini GP, Pucci L, Vanacore R et al (2007) Glucose tolerance is negatively associated with circulating progenitor cell levels. Diabetologia 50:2156-2163

43. Fadini GP, Miorin M, Facco M et al (2005) Circulating endothelial progenitor cells are reduced in peripheral vascular complications of type 2 diabetes mellitus. J Am Coll Cardiol 45:1449-1457

44. Fadini GP, Boscaro E, de Kreutzenberg S et al (2010) Time course and mechanisms of circulating progenitor cell reduction in the natural history of type 2 diabetes. Diabetes Care 33:1097-1102

45. Fadini GP, Sartore S, Albiero M et al (2006) Number and function of endothelial progenitor cells as a marker of severity for diabetic vasculopathy. Arterioscler Thromb Vasc Biol 26:2140-2146

46. Fadini GP, Maruyama S, Ozaki T et al (2010) Circulating progenitor cell count for cardiovascular risk stratification: a pooled analysis. PLoS One 5:e11488

47. Fadini GP, de Kreutzenberg S, Agostini C et al (2009) Low CD34 ${ }^{+}$ cell count and metabolic syndrome synergistically increase the risk of adverse outcomes. Atherosclerosis 207:213-219

48. Tepper OM, Galiano RD, Capla JM et al (2002) Human endothelial progenitor cells from type II diabetics exhibit impaired proliferation, adhesion, and incorporation into vascular structures. Circulation 106:2781-2786

49. Loomans CJ, de Koning EJ, Staal FJ et al (2004) Endothelial progenitor cell dysfunction: a novel concept in the pathogenesis of vascular complications of type 1 diabetes. Diabetes 53:195-199

50. Hortenhuber T, Rami-Mehar B, Satler M et al (2013) Endothelial progenitor cells are related to glycemic control in children with type 1 diabetes over time. Diabetes Care 36:1647-1653

51. Dessapt C, Karalliedde J, Hernandez-Fuentes M et al (2010) Circulating vascular progenitor cells in patients with type 1 diabetes and microalbuminuria. Diabetes Care 33:875-877

52. Brunner S, Schernthaner GH, Satler M et al (2009) Correlation of different circulating endothelial progenitor cells to stages of diabetic retinopathy: first in vivo data. Invest Ophthalmol Vis Sci 50:392-398

53. Palombo C, Kozakova M, Morizzo C et al (2011) Circulating endothelial progenitor cells and large artery structure and function in young subjects with uncomplicated type 1 diabetes. Cardiovasc Diabetol 10:88

54. Sibal L, Aldibbiat A, Agarwal SC et al (2009) Circulating endothelial progenitor cells, endothelial function, carotid intimamedia thickness and circulating markers of endothelial dysfunction in people with type 1 diabetes without macrovascular disease or microalbuminuria. Diabetologia 52:1464-1473

55. Egan CG, Lavery R, Caporali F et al (2008) Generalised reduction of putative endothelial progenitors and CXCR4-positive peripheral blood cells in type 2 diabetes. Diabetologia 51:1296-1305
56. Fadini GP, Agostini C, Sartore S, Avogaro A (2007) Endothelial progenitor cells in the natural history of atherosclerosis. Atherosclerosis 194:46-54

57. Choi JH, Kim KL, Huh W et al (2004) Decreased number and impaired angiogenic function of endothelial progenitor cells in patients with chronic renal failure. Arterioscler Thromb Vasc Biol 24:1246-1252

58. Reinhard H, Jacobsen PK, Lajer M et al (2011) Endothelial progenitor cells in long-standing asymptomatic type 1 diabetic patients with or without diabetic nephropathy. Nephron Clin Pract 118:c309-c314

59. Makino H, Okada S, Nagumo A et al (2009) Decreased circulating CD34+ cells are associated with progression of diabetic nephropathy. Diabet Med 26:171-173

60. Fadini GP, Sartore S, Baesso I et al (2006) Endothelial progenitor cells and the diabetic paradox. Diabetes Care 29:714-716

61. Tan K, Lessieur E, Cutler A et al (2010) Impaired function of circulating $\mathrm{CD} 34^{+} \mathrm{CD} 45^{-}$cells in patients with proliferative diabetic retinopathy. Exp Eye Res 91:229-237

62. Asnaghi V, Lattanzio R, Mazzolari G et al (2006) Increased clonogenic potential of circulating endothelial progenitor cells in patients with type 1 diabetes and proliferative retinopathy. Diabetologia 49:1109-1111

63. Brunner S, Hoellerl F, Schmid-Kubista KE et al (2011) Circulating angiopoietic cells and diabetic retinopathy in type 2 diabetes mellitus, with or without macrovascular disease. Invest Ophthalmol Vis Sci 52:4655-4662

64. Liu X, Li Y, Liu Y et al (2010) Endothelial progenitor cells (EPCs) mobilized and activated by neurotrophic factors may contribute to pathologic neovascularization in diabetic retinopathy. Am J Pathol 176:504-515

65. Butler JM, Guthrie SM, Koc M et al (2005) SDF-1 is both necessary and sufficient to promote proliferative retinopathy. J Clin Invest 115:86-93

66. Jeong JO, Kim MO, Kim H et al (2009) Dual angiogenic and neurotrophic effects of bone marrow-derived endothelial progenitor cells on diabetic neuropathy. Circulation 119:699-708

67. Naruse K, Hamada Y, Nakashima E et al (2005) Therapeutic neovascularization using cord blood-derived endothelial progenitor cells for diabetic neuropathy. Diabetes 54:1823-1828

68. Rohde E, Malischnik C, Thaler D et al (2006) Blood monocytes mimic endothelial progenitor cells. Stem Cells 24:357-367

69. Asakage M, Tsuno NH, Kitayama J et al (2006) Early-outgrowth of endothelial progenitor cells can function as antigen-presenting cells. Cancer Immunol Immunother 55:708-716

70. Urbich C, Heeschen C, Aicher A et al (2003) Relevance of monocytic features for neovascularization capacity of circulating endothelial progenitor cells. Circulation 108:2511-2516

71. Sica A, Mantovani A (2012) Macrophage plasticity and polarization: in vivo veritas. J Clin Invest 122:787-795

72. Mantovani A, Locati M (2013) Tumor-associated macrophages as a paradigm of macrophage plasticity, diversity, and polarization: lessons and open questions. Arterioscler Thromb Vasc Biol 33:1478-1483

73. Tan K, Lessieur E, Cutler A (2013) Macrophages and chemokines as mediators of angiogenesis. Front Physiol 4:159

74. Jetten N, Verbruggen S, Gijbels MJ et al (2013) Anti-inflammatory M2, but not pro-inflammatory M1 macrophages promote angiogenesis in vivo. Angiogenesis. doi:10.1007/s10456-0139381-6

75. Venneri MA, de Palma M, Ponzoni M et al (2007) Identification of proangiogenic TIE2-expressing monocytes (TEMs) in human peripheral blood and cancer. Blood 109:5276-5285

76. He H, Xu J, Warren CM et al (2012) Endothelial cells provide an instructive niche for the differentiation and functional polarization of M2-like macrophages. Blood 120:3152-3162 
77. Loomans CJ, van Haperen R, Duijs JM et al (2009) Differentiation of bone marrow-derived endothelial progenitor cells is shifted into a proinflammatory phenotype by hyperglycemia. Mol Med 15:152-159

78. Fadini GP, Albiero M, Boscaro E et al (2010) Rosuvastatin stimulates clonogenic potential and anti-inflammatory properties of endothelial progenitor cells. Cell Biol Int 34:709-715

79. Bories G, Caiazzo R, Derudas B et al (2012) Impaired alternative macrophage differentiation of peripheral blood mononuclear cells from obese subjects. Diab Vasc Dis Res 9:189-195

80. Satoh N, Shimatsu A, Himeno A et al (2010) Unbalanced M1/M2 phenotype of peripheral blood monocytes in obese diabetic patients: effect of pioglitazone. Diabetes Care 33:e7

81. Fadini GP, de Kreutzenberg SV, Boscaro E et al (2013) An unbalanced monocyte polarisation in peripheral blood and bone marrow of patients with type 2 diabetes has an impact on microangiopathy. Diabetologia 56:1856-1866

82. Fadini GP, Cappellari R, Mazzucato M et al (2013) Monocytemacrophage polarization balance in pre-diabetic individuals. Acta Diabetologica. doi:10.1007/s00592-013-0517-3

83. Fadini GP, Albiero M, Menegazzo L et al (2012) Procalcific phenotypic drift of circulating progenitor cells in type 2 diabetes with coronary artery disease. Exp Diabetes Res 2012:921685

84. Cui Y, Madeddu P (2011) The role of chemokines, cytokines and adhesion molecules in stem cell trafficking and homing. Curr Pharm Des 17:3271-3279

85. Hristov M, Weber C (2009) Progenitor cell trafficking in the vascular wall. J Thromb Haemost 7(1):31-34

86. Goss1 M, Modder UI, Gulati R et al (2010) Coronary endothelial dysfunction in humans is associated with coronary retention of osteogenic endothelial progenitor cells. Eur Heart J 31:2909-2914

87. Flammer AJ, Gossl M, Li J et al (2012) Patients with an HbAlc in the prediabetic and diabetic range have higher numbers of circulating cells with osteogenic and endothelial progenitor cell markers. J Clin Endocrinol Metab 97:4761-4768

88. Gossl M, Khosla S, Zhang X et al (2012) Role of circulating osteogenic progenitor cells in calcific aortic stenosis. J Am Coll Cardiol 60:1945-1953

89. Gossl M, Modder UI, Atkinson EJ, Lerman A, Khosla S (2008) Osteocalcin expression by circulating endothelial progenitor cells in patients with coronary atherosclerosis. J Am Coll Cardiol 52:1314-1325

90. Flammer AJ, Gossl M, Widmer RJ et al (2012) Osteocalcin positive CD133+/CD34-/KDR + progenitor cells as an independent marker for unstable atherosclerosis. Eur Heart J 33:2963-2969

91. Fadini GP, Rattazzi M, Matsumoto T, Asahara T, Khosla S (2012) Emerging role of circulating calcifying cells in the bone-vascular axis. Circulation 125:2772-2781

92. Fadini GP, Albiero M, Menegazzo L et al (2011) Widespread increase in myeloid calcifying cells contributes to ectopic vascular calcification in type 2 diabetes. Circ Res 108:1112-1121

93. Albiero M, Rattazzi M, Menegazzo L et al (2013) Myeloid calcifying cells promote atherosclerotic calcification via paracrine activity and allograft inflammatory factor- 1 overexpression. Basic Res Cardiol 108:368

94. Hellings WE, Peeters W, Moll FL et al (2010) Composition of carotid atherosclerotic plaque is associated with cardiovascular outcome: a prognostic study. Circulation 121:1941-1950

95. Ehara S, Kobayashi Y, Yoshiyama M et al (2004) Spotty calcification typifies the culprit plaque in patients with acute myocardial infarction: an intravascular ultrasound study. Circulation 110:3424-3429

96. Menegazzo L, Albiero M, Millioni R et al (2013) Circulating myeloid calcifying cells have anti-angiogenic activity via thrombospondin-1 overexpression. FASEB J. doi:10.1096/fj.12223719
97. Kato K, Yonetsu T, Kim SJ et al (2012) Comparison of nonculprit coronary plaque characteristics between patients with and without diabetes: a 3-vessel optical coherence tomography study. JACC Cardiovase Interv 5:1150-1158

98. Abaci A, Oguzhan A, Kahraman S et al (1999) Effect of diabetes mellitus on formation of coronary collateral vessels. Circulation 99:2239-2242

99. Fadini GP (2013) A diseased bone marrow fuels atherosclerosis in diabetes. Atherosclerosis 226:337-338

100. van Ark J, Moser J, Lexis CP et al (2012) Type 2 diabetes mellitus is associated with an imbalance in circulating endothelial and smooth muscle progenitor cell numbers. Diabetologia $55: 2501-2512$

101. Fledderus JO, van Oostrom O, de Kleijn DP et al (2013) Increased amount of bone marrow-derived smooth muscle-like cells and accelerated atherosclerosis in diabetic apoE-deficient mice. Atherosclerosis 226:341-347

102. Yu H, Stoneman V, Clarke M et al (2011) Bone marrowderived smooth muscle-like cells are infrequent in advanced primary atherosclerotic plaques but promote atherosclerosis. Arterioscler Thromb Vasc Biol 31:1291-1299

103. Bentzon JF, Sondergaard CS, Kassem M, Falk E (2007) Smooth muscle cells healing atherosclerotic plaque disruptions are of local, not blood, origin in apolipoprotein E knockout mice. Circulation 116:2053-2061

104. Bentzon JF, Weile C, Sondergaard CS et al (2006) Smooth muscle cells in atherosclerosis originate from the local vessel wall and not circulating progenitor cells in ApoE knockout mice. Arterioscler Thromb Vasc Biol 26:2696-2702

105. Fadini GP, Tjwa M (2010) A role for TGF-beta in transforming endothelial progenitor cells into neointimal smooth muscle cells. Atherosclerosis 211:32-35

106. Imamura H, Ohta T, Tsunetoshi K et al (2010) Transdifferentiation of bone marrow-derived endothelial progenitor cells into the smooth muscle cell lineage mediated by tansforming growth factor-beta1. Atherosclerosis 211:114-121

107. Westerweel PE, van Velthoven CT, Nguyen TQ et al (2010) Modulation of TGF-beta/BMP-6 expression and increased levels of circulating smooth muscle progenitor cells in a type I diabetes mouse model. Cardiovasc Diabetol 9:55

108. Nguyen TQ, Chon H, van Nieuwenhoven FA et al (2006) Myofibroblast progenitor cells are increased in number in patients with type 1 diabetes and express less bone morphogenetic protein 6: a novel clue to adverse tissue remodelling? Diabetologia 49:1039-1048

109. Zheng F, Cornacchia F, Schulman I et al (2004) Development of albuminuria and glomerular lesions in normoglycemic B6 recipients of $d b / d b$ mice bone marrow: the role of mesangial cell progenitors. Diabetes 53:2420-2427

110. Menegazzo L, Albiero M, Avogaro A, Fadini GP (2012) Endothelial progenitor cells in diabetes mellitus. Biofactors 38:194-202

111. Fadini GP (2011) Is bone marrow another target of diabetic complications? Eur J Clin Invest 41:457-463

112. Fadini GP, Sartore S, Schiavon M et al (2006) Diabetes impairs progenitor cell mobilisation after hindlimb ischaemia-reperfusion injury in rats. Diabetologia 49:3075-3084

113. Ferraro F, Lymperi S, Mendez-Ferrer S et al (2011) Diabetes impairs hematopoietic stem cell mobilization by altering niche function. Sci Transl Med 3:104ra101

114. Fadini GP, Avogaro A (2013) Diabetes impairs mobilization of stem cells for the treatment of cardiovascular disease: a meta-regression analysis. Int J Cardiol 168:892-897

115. Fadini GP, Albiero M, Vigili de Kreutzenberg S et al (2013) Diabetes impairs stem cell and proangiogenic cell mobilization in humans. Diabetes Care 36:943-949 
116. Oikawa A, Siragusa M, Quaini F et al (2010) Diabetes mellitus induces bone marrow microangiopathy. Arterioscler Thromb Vasc Biol 30:498-508

117. Spinetti G, Cordella D, Fortunato O et al (2013) Global remodeling of the vascular stem cell niche in bone marrow of diabetic patients: implication of the microRNA-155/FOXO3a signaling pathway. Circ Res 112:510-522

118. Mangialardi G, Katare R, Oikawa A et al (2013) Diabetes causes bone marrow endothelial barrier dysfunction by activation of the RhoA-Rho-associated kinase signaling pathway. Arterioscler Thromb Vasc Biol 33:555-564

119. Fadini GP, Avogaro A (2013) Dipeptidyl peptidase-4 inhibition and vascular repair by mobilization of endogenous stem cells in diabetes and beyond. Atherosclerosis 229:23-29

120. Esposito K, Maiorino MI, Di Palo C et al (2011) Effects of pioglitazone versus metformin on circulating endothelial microparticles and progenitor cells in patients with newly diagnosed type 2 diabetes-a randomized controlled trial. Diabetes Obes Metab $13: 439-445$

121. Zhao CT, Wang M, Siu CW et al (2012) Myocardial dysfunction in patients with type 2 diabetes mellitus: role of endothelial progenitor cells and oxidative stress. Cardiovasc Diabetol 11:147
122. Hazra S, Jarajapu YP, Stepps V et al (2013) Long-term type 1 diabetes influences haematopoietic stem cells by reducing vascular repair potential and increasing inflammatory monocyte generation in a murine model. Diabetologia 56:644-653

123. Orlandi A, Chavakis E, Seeger F et al (2010) Long-term diabetes impairs repopulation of hematopoietic progenitor cells and dysregulates the cytokine expression in the bone marrow microenvironment in mice. Basic Res Cardiol 105:703-712

124. Westerweel PE, Teraa M, Rafii S et al (2013) Impaired endothelial progenitor cell mobilization and dysfunctional bone marrow stroma in diabetes mellitus. PLoS One 8:e60357

125. Fadini GP, Albiero M, Seeger F et al (2013) Stem cell compartmentalization in diabetes and high cardiovascular risk reveals the role of DPP-4 in diabetic stem cell mobilopathy. Basic Res Cardiol 108:313

126. Busik JV, Tikhonenko M, Bhatwadekar A et al (2009) Diabetic retinopathy is associated with bone marrow neuropathy and a depressed peripheral clock. J Exp Med 206:2897-2906

127. Ling L, Shen Y, Wang K et al (2012) Worse clinical outcomes in acute myocardial infarction patients with type 2 diabetes mellitus: relevance to impaired endothelial progenitor cells mobilization. PLoS One 7:e50739 